\title{
Effects of Stocking Biomass on Growth, Survival, and Production of the two Sizes of Clam Meretrix lyrata Cultured in the Intertidal Areas
}

NHU VAN CAN ${ }^{* 1}$, CHU CHI THIET ${ }^{1}$ and MARTIN S KUMAR ${ }^{2}$

${ }^{1}$ Research Institute for Aquaculture No1 (RIA1), Dinh-bang, Tu-son, Bac-ninh, Vietnam

${ }^{2}$ South Australian Research and Development Institute (SARDI), Australia

\begin{abstract}
The triplicate experiment had been conducted in $50 \mathrm{~m}^{2}$ plots randomly placed in the intertidal areas to evaluate the effects of stocking biomass on survival, growth performance, and quality of clam Meretrix lyrata. The two stocking sizes (Mean $\pm \mathrm{SD}, \mathrm{cm}$ ) at shell length of $1.0 \pm 0.2$ and $1.7 \pm 0.1$ were scattered at different biomass: $0.05,0.1,0.2,0.3 \mathrm{~kg} . \mathrm{m}^{-2}$ and 0.34 , 0.68, 1.36, $2.03 \mathrm{~kg} . \mathrm{m}^{-2}$ and named as T1, T2, T3, T4 and T5, T6, T7, T8, respectively. Results show that meat ratio of the clam were similar regardless of different stocking biomass. The fatty acids were rich in highly unsaturated fatty acids especially docosahexaenoic acid but were variable. In contrast, growth and survival of the clam were strongly affected by the stocking biomass in which the lower stocking biomass resulted in higher specific growth rate (SGR) and survival rate. The biomass gained therefore reduced accordingly with increase in the stocking biomass, although the increase of final production was evident. However, SGR and survival of the treatments T1, T2, and T3 were not significantly different, suggesting the highest net profit and investment return of the treatment T3. Therefore, the stocking biomass of 0.2 $\mathrm{kg} . \mathrm{m}^{2}$ was recommended to maximize profit of the clam cultivation.
\end{abstract}

\section{Introduction}

The mollusk production has been increasing steadily during the last two decades (Gibbs 2004) and has reached the total production of $13.25 \mathrm{mmt}$, which accounts for $23.3 \%$ of total world aquaculture production in 2004 (Tacon \& Halwart 2006). Among mollusk species, the bivalve shellfish are not only the favorable seafood but also are regarded as the most ecologically efficient forms of aquaculture because these are low trophic-level animals. Besides, bivalve shellfish are filter feeders, which can also be used as biofilter for improvement of water quality (Shpigel \& Blaylock 1991; Shpigel et al. 1993; Shpigel et al. 1997; Mazzola \& Sara 2001) and thus contribute to the sustainable aquaculture development.

\footnotetext{
*Corresponding Author. Tel: +84-383829884; Mob: +84-913025788;

Email : nhuvancan@yahoo.com
} 
Clams belong to bivalve shellfish but they are different from the others by dwelling on the bottom. Researches have been carried out on the production of various clam species (Shpigel \& Spencer 1996; Cigarrýa \& Fernandez 2000; Zhang \& Yan 2006) and the use of clam for improvement of water quality (Shpigel \& Fridman 1990; Jara-Jara et al. 1997). In Vietnam, the endogenous brackish water clam Meretrix lyrata (M. lyrata) is an emerging cultured species for coastal aquaculture because this is favorable seafood in the national and international markets. $M$. lyrata distributes naturally in the intertidal of southern coast and known as "Ngheu Ben Tre" because the exploited production mostly comes from Ben Tre province, south of Vietnam. Recently, due to high consumption demand, M. lyrata is being cultivated and expanded to the northern coastal provinces such as in Nam Dinh, Thanh Hoa, Nghe An, and Ha Tinh. However, the clam production still is very unstable and unpredictable due to poor management. The technical information on clam culture still is very limited. Therefore, it is necessary to study the establishment of a standard protocol to enhance the production and profit of clam culture.

Among the factors that affect growth and production, feed and feeding of clam have been regarded as the most important factors. Researches recently have revealed that feed clearance rate have positive relationship with body size, and within a range of food concentration, their feeding can be strongly affected by substrata (Zhuang \& Wang 2004) and by salinity or diurnal rhythm (Zhuang 2006). For maximizing production and profit, Zhang \& Yan (2006) described a new three-phase culture method for Manila clam farming in China. In this method, the seed was artificially produced indoor during winter and the grow-out phase was conducted in the intertidal with appropriate stocking size, stocking density, and substrate. In the intertidal areas where the feed are naturally dependent, uncontrollable, and variable, stocking biomass becomes an important factor to increase the growth and production. The objective of this research was to evaluate the effect of stocking biomass of the two sizes of M. lyrata on growth performance and survival to enhance the production and profit of cultivation. The other parameters within the culture system cannot be altered as it is a natural ecosystem highly connected to capture fisheries, which is one of the key industries for the fishery community.

\section{Materials and Methods}

The experiment had been conducted in the intertidal areas that belong to Hau Loc District, Thanh Hoa Province. There were 24 plots of $50 \mathrm{~m}^{2}$ each, separated by plastic mesh and randomly allocated for eight treatments (three replicates each). The small clam seeds at shell length of $1.0 \pm 0.2 \mathrm{~cm}$ were scattered at four different biomass: 0.05 , $0.10,0.20$, and $0.30 \mathrm{~kg} \cdot \mathrm{m}^{-2}$ and named as T1, T2, T3, and T4, respectively. The bigger size of clam seed at a shell length of $1.7 \pm 0.1 \mathrm{~cm}$ was stocked at 4 different stocking biomass: $0.34,0.68,1.36$, and $2.03 \mathrm{~kg} \cdot \mathrm{m}^{2}$ and named as T5, T6, T7, and T8, respectively. This experiment was terminated after 165 days of rearing. Environment factors such as temperature (thermal meter), DO, $\mathrm{pH}$ (Oxyguard), turbidity (Sechi disk), and salinity 
(Refractometer) of water in the experiment site were daily monitored at 3 designated points within the experimental area.

Growth of clam, expressed in mean of shell length $(\mathrm{cm})$ and mean of live weight $(\mathrm{g})$, was determined by random sampling $(\mathrm{n}=30)$ and was measured every fortnight. The daily specific growth rate (SGR) was calculated using the following formula (JaraJara et al. 1997):

$$
\operatorname{SGR}\left(\% \cdot \text { day }^{-1}\right)=100 *\left(\operatorname{LnW}_{-}-\operatorname{LnW}_{\mathrm{i}}\right) / \mathrm{t} .
$$

Where $\mathrm{W}_{\mathrm{i}}$ and $\mathrm{W}_{\mathrm{f}}$ are mean of initial weight and final weight, respectively, and $\mathrm{t}$ is number of experiment days. Size variation of the clam was evaluated according to Wang et al. (1998) in which the mean of three replicates of the coefficient of variation (CV) was used to examine the inter-individual variation among the clam in each treatment: $\mathrm{CV}(\%)=100 * \mathrm{SD} / \mathrm{M}$, where $\mathrm{M}$ is mean of live weight, and $\mathrm{SD}$ is standard deviation of the clam in each treatment. The meat ratio (\% of meat weight: total live weight) of clam was conducted by separating the meat content of random samples ( $\mathrm{n}=$ 20). The excess water was removed by placing the sample on tissue paper.

At the end of experiment, clam was randomly sampled and preserved in Liquid Nitrogen Biological Container (YDS-3, $-196^{\circ} \mathrm{C}$ ) for the analysis of fatty acids. The fatty acids content expressed in mg. $\mathrm{g}^{-1}$ dry weight was first extracted by placing the clam in a $35-\mathrm{mL}$ glass tube with a teflon lined screw caps and $5 \mathrm{~mL}$ of methanol/toluene mixture $(3: 2 \mathrm{v} / \mathrm{v})$ was added; then, $0.1 \mathrm{~mL}$ of internal standard solution containing 4.78 mg.mL $\mathrm{mL}^{-1}$ 20:2(n-6) fatty acid dissolved in iso-octane was added. The freshly prepared acetylchloride/methanol mixture $(1: 20 \mathrm{v} / \mathrm{v})$ then was added as the esterification reagent. The tube was flushed with nitrogen gas and closed tightly before carefully shaking and was placed in a boiling water bath $\left(100^{\circ} \mathrm{C}\right)$. After one hour, the tube was cooled, $5 \mathrm{~mL}$ of distilled water and $5 \mathrm{~mL}$ of hexane were added, and the upper layer was separated by centrifugation. The combined hexane phase was dried by filtration process carried out in a flask using the anhydrous sodium sulphate filter, and the FAMEs were finally dissolved in $0.5 \mathrm{~mL}$ iso-octane and transferred in a 2-mL glass vial for injection in Finnigan Trace GC untra with capillary column BP-70 (50m x $0.32 \mathrm{~mm} \times 0.25 \mu \mathrm{m})$. All data of the treatments were tested for significant differences $(\mathrm{p}<0.05)$ using One-way ANOVA followed by Turky test for multiple comparisons of means. The data are expressed as Average \pm SD, and the statistical analysis was carried out using GraphPad Prism version 4.0 and Microsoft Office EXCEL for Window.

\section{Results and Discussion}

\section{Environment conditions of the experiments}

The experiment site situated the intertidal areas near the estuary where the clams 
have been already cultivated for recent years. The environment factors such as DO, water temperature, $\mathrm{pH}$, and salinity (Table 1) were regarded as the best conditions for clam development. The high levels of salinity fluctuation are typical for estuary ecological conditions. The average water temperature was $23.59 \pm 2.40^{\circ} \mathrm{C}$, relatively low compared with the normal water temperature in the south of Vietnam, where M. lyrata is naturally distributed. This mean clam is not affected by the marked variation and good growth and survival rate were noticed. However, low water temperature might affect growth performance, and the growth and survival of M. lyrata might be not as high as the ones cultivated in the south of Vietnam. As Soudanta et al. (2004) has described, in the Manila clam cultured in four rearing sites that were selected for their varied ecological characteristics, it was observed that the environmental conditions influenced the physiological and immunological parameters."

Table 1. Environment conditions in the experiment site

\begin{tabular}{lccccc}
\hline Parameters & DO $(\mathrm{ppm})$ & Water temperature $\left({ }^{\circ} \mathrm{C}\right)$ & $\mathrm{pH}$ & Salinity $(\mathrm{ppt})$ & Turbidity $(\mathrm{cm})$ \\
\hline Average $\pm \mathrm{SD}$ & $6.25 \pm 0.42$ & $23.59 \pm 2.40$ & & $25.65 \pm 2.84$ & $9.05 \pm 3.13$ \\
Maximum & 7.66 & 31.00 & 8.99 & 31.00 & 20.00 \\
Minimum & 5.50 & 19.50 & 7.21 & 20.00 & 5.00 \\
\hline
\end{tabular}

\section{Growth performance}

The growth performance of the two stocking sizes of M. lyrata at different stocking biomass expressed in specific growth rate, final shell length, and final live weight as well as size variation are shown in Tables 2 and 3.

Table 2. Growth performance of clam at stocking size of $1.0 \mathrm{~cm}$

\begin{tabular}{lcccc}
\hline Treatments & T1 & T2 & T3 & T4 \\
\hline SGR & $1.25 \pm 0.05^{\mathrm{a}}$ & $1.13 \pm 0.05^{\mathrm{a}}$ & $1.08 \pm 0.10^{\mathrm{ab}}$ & $0.94 \pm 0.37^{\mathrm{b}}$ \\
Final length (cm) & $2.04 \pm 0.13^{\mathrm{a}}$ & $2.01 \pm 0.09^{\mathrm{ab}}$ & $1.95 \pm 0.10^{\mathrm{b}}$ & $1.95 \pm 0.11^{\mathrm{b}}$ \\
Final weight (g) & $5.92 \pm 1.08^{\mathrm{a}}$ & $5.76 \pm 0.81^{\mathrm{ab}}$ & $5.46 \pm 0.76^{\mathrm{ab}}$ & $5.30 \pm 0.85^{\mathrm{b}}$ \\
\% of meat.total weight & $15.87 \pm 1.00^{\mathrm{a}}$ & $15.48 \pm 2.72^{\mathrm{a}}$ & $15.53 \pm 1.02^{\mathrm{a}}$ & $15.15 \pm 5.47^{\mathrm{a}}$ \\
CV\% (weight) & $28.72 \pm 2.55^{\mathrm{a}}$ & $23.07 \pm 0.24^{\mathrm{b}}$ & $23.73 \pm 1.55^{\mathrm{b}}$ & $27.78 \pm 2.11^{\mathrm{ab}}$ \\
\hline
\end{tabular}

Value (Mean $\pm \mathrm{SD}$ ) followed by different superscript letters within a row are significantly different $(P<0.05)$. T1, T2, T3, and T4 are treatments of clam cultured at $0.05,0.1,0.2$, and $0.3 \mathrm{~kg} . \mathrm{m}^{-2}$, respectively. $\mathrm{SGR}=$ daily specific growth rate; $\mathrm{CV}=$ coefficient of variation 
Table 3. Growth performance of clam at stocking size of $1.7 \mathrm{~cm}$

\begin{tabular}{lcccc}
\hline Treatments & T5 & T6 & T7 & T8 \\
\hline SGR & $0.62 \pm 0.04^{\mathrm{a}}$ & $0.46 \pm 0.03^{\mathrm{b}}$ & $0.33 \pm 0.02^{\mathrm{c}}$ & $0.32 \pm 0.02^{\text {cd }}$ \\
Final length (mm) & $2.36 \pm 0.17^{\mathrm{ab}}$ & $2.40 \pm 0.10$ & $2.32 \pm 0.11^{\mathrm{bc}}$ & $2.27 \pm 0.10^{\mathrm{c}}$ \\
Final weight (g) & $9.24 \pm 1.20^{\mathrm{a}}$ & $9.33 \pm 0.95^{\mathrm{a}}$ & $8.90 \pm 1.12^{\mathrm{a}}$ & $8.21 \pm 1.01^{\mathrm{b}}$ \\
\% of meat.total weight $14.53 \pm 1.89^{\mathrm{a}}$ & $15.78 \pm 2.35^{\mathrm{a}}$ & $16.53 \pm 0.62^{\mathrm{a}}$ & $15.48 \pm 1.31^{\mathrm{a}}$ \\
CV\% (weight) & $22.3 \pm 0.45^{\mathrm{a}}$ & $19.05 \pm 5.16^{\mathrm{a}}$ & $18.69 \pm 3.36^{\mathrm{a}}$ & $22.73 \pm 4.16^{\mathrm{a}}$ \\
\hline
\end{tabular}

Value (Mean \pm SD) followed by different superscript letters within a row are significantly different $(p<0.05)$. T5, T6, T7, and T8 are treatments of clam cultured at $0.34,0.68,1.36$, and $2.06 \mathrm{~kg} . \mathrm{m}^{-}$ ${ }^{2}$, respectively. SGR = daily specific growth rate; $\mathrm{CV}=$ coefficient of variation.

For the small-size group, there was no significant difference in specific growth rate and final weight among T1, T2, and T3 treatments (Table 2), indicating that growth of the clams were not affected by the stocking biomass below $0.2 \mathrm{~kg} \cdot \mathrm{m}^{-2}$. The final size of M. lyrata was more variable at low (T1) and high (T4) stocking density compared with the medium (T2 and T3) ones. The meat yield expressed in percentage of meat per total weight, which is regarded as the most valuable part of the clams, was not significantly different $(p>0.05)$ in all treatments

The growth of $M$. lyrata at stocking size of $1.7 \mathrm{~cm}$ significantly reduced with an increase in the stocking biomass (Table 3). At high stocking biomass (T7 and T8), the SGRs were relatively low and were not significantly different. The final length and final weight of the treatment T8 were significantly smaller compared with others. However, the size variation was not affected by different stocking biomass.

In general, at younger stage, the animal has better growth rate. In the case of clam, at the same stocking biomass, the small-size clam $(1.0 \mathrm{~cm})$ grew much better than the large-size clam $(1.7 \mathrm{~cm})$. In the intertidal areas, the natural feed and environmental factors are uncontrollable and are dependent of nature. Dynamics of tide, wave, and current create the availability of algae, organic matter that is regarded as feed for clam. However, because clam is filter feeder and passively dwells on the bottom, the amount of biomass decreases beyond certain level and hence the natural feed might not be enough for its growth. Moreover, in treatments of the same size organisms, increasing biomass led to the increase in the competition of other environmental conditions such as habitat, DO, and increased accumulation of metabolic wastes, that is feces, which is regarded as a detriment for the growth of clam (Yan et al. 2006). It was also observed that at the same temperature, the clearance rate and ingestion rate of clam increased exponentially with an increase in the size (Zhuang and Wang, 2004). Results of the 
growth performance (Table 3) indicated that at high stocking biomass (more than 0.3 $\mathrm{kg} \cdot \mathrm{m}^{-2}$ ), the growth could be inhibited, and the growth rate significantly reduced with an increase in the biomass. In addition, it was noted that winter is not an appropriate culture period because the water temperature is normally low and does not support the growth of $M$. lyrata, the tropical species.

\section{Survival}

The stocking biomass influenced the survival rate in both the sizes of clam. Survival was very high in the low stocking biomass treatment (T1) and was almost similar in the treatments $\mathrm{T} 2$ and $\mathrm{T} 3$. As seen in figure 1 the treatment $\mathrm{T} 1$ was significantly different $(p<0.05)$ from the treatment $\mathrm{T} 4$.

In the larger stocking groups, survival of the treatment T5 was highest followed by the treatment $\mathrm{T} 6$. Survival of the treatment $\mathrm{T} 7$ and treatment $\mathrm{T} 8$ were very low and were not significantly different (Fig 2). On the other hand, the results presented in figures 1 and 2 also indicate that the clam survival is not only affected by the stocking biomass but also affected by the stocking density. The environmental condition and food availability could be explained as the main reasons for the impact of the stocking biomass on survival rate.

Stocking size had been detected to affect survival of the Manila clam in which the small-size group showed higher mortality; however, substrata or predators are

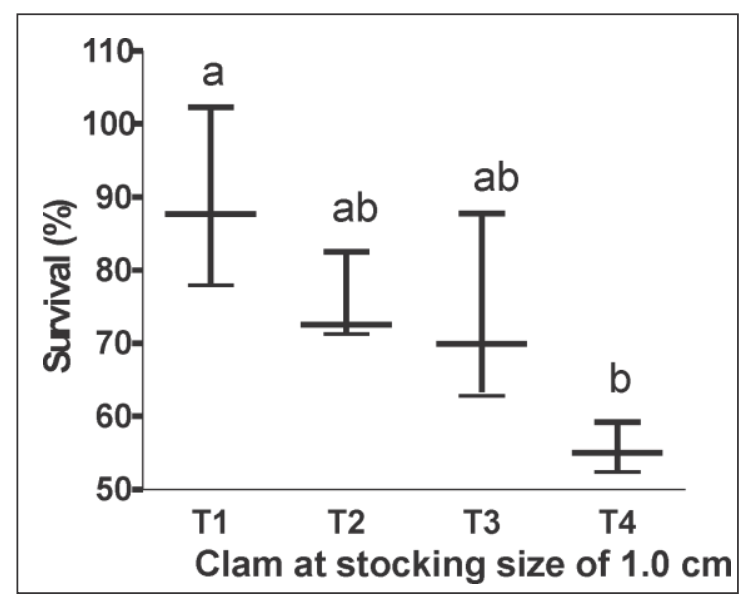

Figure 1. Survival of clam size $1.0 \mathrm{~cm}$ rearing at different stocking biomass. (Value (Average \pm SD) followed by different superscript letters are significantly different $(\mathrm{p}<0.05)$. T1, T2, T3, and $\mathrm{T} 4$ are treatments of clam cultured at $0.05,0.1,0.2$, and $0.3 \mathrm{~kg} \cdot \mathrm{m}^{-2}$, respectively).

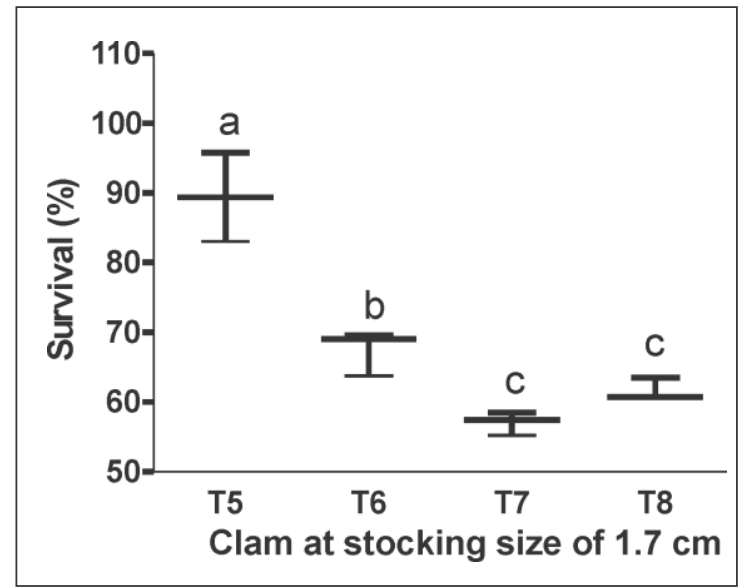

Figure 2. Survival of clam size $1.7 \mathrm{~cm}$ rearing at different stocking biomass. (Value (Average \pm SD) followed by different superscript letters are significantly different $(\mathrm{P}<0.05)$. T5, T6, T7 and T8 are treatments of clam size $1.7 \mathrm{~cm}$ cultured at 0.34 , $0.68,1.36$ and $2.06 \mathrm{~kg} . \mathrm{m}-2$ respectively). 
not the only reason for this high mortality rate (Cigarrýa \& Fernandez 2000), and the normal stocking size of this species for intertidal cultivation was $1.0 \mathrm{~cm}$ (Zhang \& Yan 2006). In our trial, at same stocking biomass $\left(0.30\right.$ and $\left.0.34 \mathrm{~kg} \cdot \mathrm{m}^{-2}\right)$, survival rate of treatment T4 $(1.0 \mathrm{~cm})$ was very low $(55 \%)$ compared with survival rate of $90 \%$ of the treatment T5 $(1.7 \mathrm{~cm})$. Within the same size $1.7 \mathrm{~cm}$, the treatment $\mathrm{T} 7$ and $\mathrm{T} 8$ had relatively low survival rate compared with the treatment $\mathrm{T} 5$ and $\mathrm{T} 6$, suggesting that those stocking biomass were too high for the development of clam.

\section{Production and quality}

Both growth and survival was considered for the estimation of the production of clam. There was a positive relationship between the clam production and stocking biomass, although the growth and survival were negatively affected. Among the small stocking size group, the final production increased accordingly with the gain in biomass and no significant difference ( $\mathrm{p}>0.05$ ) was detected between T1 and T2 and T3 and T4 (Table 4). The percentage of biomass gained, in contrast, showed a decreasing trend as the stocking biomass increased. No significant difference was detected between T1 and T4. This is due the fact that the increase in biomass negatively affected the growth and survival of the clams.

Table 4. Biomass production of clam at stocking size of $1.0 \mathrm{~cm}$

\begin{tabular}{lcccc}
\hline Treatments & T1 & T2 & T3 & T4 \\
\hline Final production (ton.ha ${ }^{-1}$ ) & $4.14 \pm 0.57^{\mathrm{a}}$ & $6.82 \pm 0.56^{\mathrm{a}}$ & $12.62 \pm 2.16^{\mathrm{b}}$ & $14.84 \pm 0.91^{\mathrm{b}}$ \\
Biomass gained (ton.ha $\left.^{-1}\right)$ & $3.62 \pm 0.57^{\mathrm{a}}$ & $5.78 \pm 0.56^{\mathrm{a}}$ & $10.54 \pm 2.16^{\mathrm{b}}$ & $11.72 \pm 0.91^{\mathrm{b}}$ \\
$\%$ of biomass gained & $697.1 \pm 109.4^{\mathrm{a}}$ & $555.8 \pm 53.6^{\mathrm{ab}}$ & $506.9 \pm 104.0^{\mathrm{ab}}$ & $375.8 \pm 29.3^{\mathrm{b}}$ \\
\hline
\end{tabular}

Value (Mean $\pm \mathrm{SD}$ ) followed by different superscript letters within a row are significantly different $(p<0.05)$. T1, T2, T3, and T4 are treatments of clam cultured at $0.05,0.1,0.2$, and $0.3 \mathrm{~kg} \cdot \mathrm{m}^{-2}$, respectively

In the larger stocking size $(1.7 \mathrm{~cm})$, the final production of the clam significantly increased with an increase in the stocking biomass $(\mathrm{p}<0.05)$. The percentage of biomass gained, in contrast, decreased with an increase in the stocking biomass in T5, T6, and T7 (Table 5). However, no significant difference $(p>0.05)$ was observed in the biomass gained in the treatment T5 and T6 and percentage of biomass gained in the treatments 
$\mathrm{T} 7$ and T8. In both size groups, the increase in biomass certainly had a negative impact on the net production.

Table 5. Biomass production of clam at stocking size of $1.7 \mathrm{~cm}$

\begin{tabular}{lcccc}
\hline Treatments & T5 & T6 & T7 & T8 \\
\hline Final production (ton.ha ${ }^{-1}$ ) & $9.49 \pm 0.68^{\mathrm{a}}$ & $14.46 \pm 0.69^{\mathrm{b}}$ & $23.58 \pm 0.68^{\mathrm{c}}$ & $34.80 \pm 1.00^{\mathrm{d}}$ \\
Biomass gained (ton.ha $\left.{ }^{-1}\right)$ & $6.10 \pm 0.68^{\mathrm{a}}$ & $7.68 \pm 0.69^{\mathrm{a}}$ & $10.02 \pm 0.69^{\mathrm{b}}$ & $14.46 \pm 0.99^{\mathrm{c}}$ \\
\% of biomass gained & $180.0 \pm 20.0^{\mathrm{a}}$ & $113.3 \pm 10.1^{\mathrm{b}}$ & $73.9 \pm 5.1^{\mathrm{c}}$ & $71.1 \pm 4.8^{\mathrm{c}}$ \\
\hline
\end{tabular}

Value (Mean \pm SD) followed by different superscript letters within a row are significantly different $(p<0.05)$. T5, T6, T7, and T8 are treatments of clam cultured at 0.34, 0.68, 1.36, and $2.06 \mathrm{~kg} \cdot \mathrm{m}^{-2}$, respectively.

The high value of percentage of biomass gained confirmed that the stocking biomass was barrier for the development of clam. However, the increase in the biomass gained as well as final production indicated that the determination of appropriate stocking biomass is important for the production of clam. The economic calculation therefore is vital to optimize investment benefit.

\section{Fatty acid profile}

There was difference in the fatty acid profiles between treatments regardless of different stocking biomass. The total FAME varies from 134.4 to $193.7 \mathrm{mg} . \mathrm{g}^{-1} \mathrm{dry}$ weight (Table 6). However, the presence of high content of HUFA especially DHA content ( 29.00 to $62.77 \mathrm{mg} . \mathrm{g}^{-1}$ dry weight) indicated the value of clam as seafood product. The variation observed in the amount of fatty acids in clam may be attributed to the development of ovary and/or growing development stage when the fatty acids normally accumulate. Our result confirmed the variation in the amount of fatty acid of clam Ruditapes decussatus reared in sea water and effluent from a fish farm in Galicia (JaraJara et al. 1997). The variation in the amount of fatty acid and the factors affecting this variation need a further research.

\section{Economic evaluation}

The estimation of the economic benefit of clam cultured in the intertidal areas is shown in Table 7. The net profit is calculated based on the output cost, input cost, and price of the clam. 
Table 6. Fatty acids of clam cultured at different stocking sizes and different stocking biomass

\begin{tabular}{|c|c|c|c|c|c|c|c|c|}
\hline Fatty Acids & $\mathrm{T} 1$ & $\mathrm{~T} 2$ & $\mathrm{~T} 3$ & $\mathrm{~T} 4$ & T5 & T6 & $\mathrm{T} 7$ & $\mathrm{~T} 8$ \\
\hline 14:00 & 0.58 & - & - & 1.07 & - & 0.59 & 2.52 & 6.35 \\
\hline 16:00 & 44.26 & 42.67 & 78.27 & 21.63 & 47.07 & 84.63 & 33.54 & 33.94 \\
\hline $16: 1(n-7)$ & 9.85 & - & 3.53 & 7.88 & - & 0.75 & 10.94 & 11.71 \\
\hline 17:00 & 0.19 & - & - & 0.89 & - & - & 1.94 & 1.22 \\
\hline $17: 1(n-7)$ & - & - & - & - & - & - & 3.39 & 7.71 \\
\hline 18:00 & 4.63 & 15.63 & 22 & 23.98 & 16.82 & 7.84 & 10.08 & 10.72 \\
\hline $18: 1(n-9)$ & 63.02 & 39.79 & 26.83 & 29.68 & 49.38 & 33.41 & 27.18 & 31.94 \\
\hline $18: 1(n-7)$ & - & - & - & 5.31 & 6.33 & - & - & - \\
\hline $18: 2(n-6) t$ & 0.41 & 8.19 & - & 1.06 & - & - & 2.35 & 13.74 \\
\hline $18: 3(n-3)$ & - & - & - & 0.54 & - & - & 1.1 & 5.16 \\
\hline 20:1(n-9) & - & 7.83 & - & 0.52 & 8.18 & - & - & - \\
\hline $20: 4(n-6)$ & 1.11 & - & 7.72 & 2.98 & 5.06 & 2.72 & 3.54 & 8.9 \\
\hline $20: 4(n-3)$ & - & - & - & 0.31 & - & - & - & - \\
\hline $20: 5(n-3)$ & 4.45 & 3.11 & - & 5.95 & 6.2 & 0.97 & 7.96 & 3.29 \\
\hline 24:00:00 & - & - & - & 1.17 & - & - & - & - \\
\hline $22: 5(n-6)$ & - & - & - & - & - & - & 1.56 & - \\
\hline $22: 5(n-3)$ & - & 3 & 4.96 & 1.85 & - & - & 2.46 & - \\
\hline $22: 6(n-3)$ & 45.78 & 29 & 33.62 & 29.65 & 27.58 & 62.77 & 30.4 & 30.0 \\
\hline Sum (n-3) & 50.23 & 35.11 & 38.58 & 37.76 & 33.78 & 63.74 & 40.82 & 30.29 \\
\hline Sum (n-6) & 0.11 & 0 & 7.72 & 2.98 & 5.06 & 2.72 & 5.1 & 8.9 \\
\hline Sum HUFA & 50.34 & 35.11 & 46.3 & 40.74 & 38.84 & 66.46 & 45.92 & 42.19 \\
\hline Total FAME & 174.3 & 149.2 & 176.9 & 134.4 & 166.6 & 193.7 & 139 & 166.1 \\
\hline
\end{tabular}

Value $=\mathrm{mg} . \mathrm{g}^{-1}$ dry weight; $\mathrm{T} 1, \mathrm{~T} 2, \mathrm{~T} 3$ and $\mathrm{T} 4$ are treatments of clam cultured at $0.05,0.1,0.2$ and $0.3 \mathrm{~kg} \cdot \mathrm{m}^{-2}$ respectively; T5, T6, T7 and T8 are treatments of clam size $1.7 \mathrm{~cm}$ cultured at $0.34,0.68,1.36$ and $2.06 \mathrm{~kg} . \mathrm{m}^{-2}$ respectively. 
Table 7. Economical evaluation of the two stocking size of clam rearing at different stocking biomass

\begin{tabular}{|c|c|c|c|c|c|c|c|c|}
\hline \multirow{2}{*}{$\begin{array}{l}\text { Stocking size } \\
\text { Treatments }\end{array}$} & \multicolumn{4}{|c|}{ Shell length $1.0 \mathrm{~cm}$} & \multicolumn{4}{|c|}{ Shell length $1.7 \mathrm{~cm}$} \\
\hline & $\mathrm{T} 1$ & $\mathrm{~T} 2$ & $\mathrm{~T} 3$ & $\mathrm{~T} 4$ & T5 & T6 & $\mathrm{T} 7$ & T8 \\
\hline Stocking biomass (ton.ha ${ }^{-1}$ ) & 0.50 & 1.00 & 2.00 & 3.00 & 3.40 & 6.80 & 13.60 & 20.40 \\
\hline Final production (ton.ha-1) & 4.14 & 6.82 & 12.62 & 14.84 & 9.49 & 14.46 & 23.58 & 34.80 \\
\hline \multicolumn{9}{|l|}{ Input (* mill VND.ha $\left.a^{-1}\right)$} \\
\hline Cost for seed (1) & 17.50 & 35.00 & 70.00 & 105.00 & 61.20 & 122.40 & \multicolumn{2}{|c|}{244.80367 .20} \\
\hline Mesh and fencing & 3.30 & 3.30 & 3.30 & 3.30 & 3.30 & 3.30 & 3.30 & 3.30 \\
\hline Labor cost & 7.20 & 7.20 & 7.20 & 7.20 & 7.20 & 7.20 & 7.20 & 7.20 \\
\hline Hut for daily monitoring & 5.00 & 5.00 & 5.00 & 5.00 & 5.00 & 5.00 & 5.00 & 5.00 \\
\hline Land lease & 4.00 & 4.00 & 4.00 & 4.00 & 4.00 & 4.00 & 4.00 & 4.00 \\
\hline Harvesting cost $(\mathrm{B} * 2 \%)$ & 0.99 & 1.64 & 3.03 & 3.56 & 2.28 & 3.47 & 5.66 & 8.35 \\
\hline Total input (A) & 37.99 & 56.14 & 92.53 & 128.06 & 82.98 & 145.37 & \multicolumn{2}{|c|}{269.96395 .05} \\
\hline \multicolumn{9}{|c|}{ Output (* mill VND.ha-1 with assumption price of 12 mill VND.ton ${ }^{-1}$ for all harvested clam) } \\
\hline Total output (B) & 49.72 & 81.82 & 151.44 & 178.08 & 113.90 & 173.52 & \multicolumn{2}{|c|}{282.96417 .60} \\
\hline Net profit $(A-B)$ & 11.72 & 25.68 & 58.91 & 50.02 & 30.93 & 28.15 & 13.00 & 22.55 \\
\hline Rate of investment return (\% & )30.85 & 45.75 & 63.67 & 39.06 & 37.27 & 19.36 & 4.82 & 5.71 \\
\hline
\end{tabular}

(1) The seed cost was 0.035 mill VND.kg-1 size $1.0 \mathrm{~cm}$ and 0.018 mill VND. $\mathrm{kg}^{-1}$ size $1.7 \mathrm{~cm}$

The main cost in $M$. lyrata cultivation was the expense in seed purchase. Cost of seed ranged between $46 \%$ and $81 \%$ in small-size seed $(1.0 \mathrm{~cm})$ for the four treatments (T1, T2, T3, and T4). As all other costs are fixed, the increase in stocking biomass increased the total cost invested. Although total production increased with the increase in stocking biomass, the economic analysis clearly indicated that the net profit decreased beyond the level of 2 ton.ha-1 ${ }^{-1}$ stocking biomass (T3). The treatment T4 with the stocking density of 3 ton.ha ${ }^{-1}$ yielded lesser net profit compared with the treatment T3. This can be explained by the higher proportion of seed cost while the biomass gained was lower due to less growth and survival. Therefore, the stocking biomass of 2 ton.ha $^{-1}$ is recommended for M. lyrata at stocking size of $1.0 \mathrm{~cm}$.

For the treatment T5, T6, T7, and T8, cost of seed increased from $73.8 \%$ to $92.9 \%$. Because the price of seed was higher than the price of harvested clam, while the biomass gained reduced accordingly with increase in stocking biomass, the net profit was reduced and relatively lower compared with the $1-\mathrm{cm}$ seed stocking treatments. We suggested that the clam size more than $1.7 \mathrm{~cm}$ should not be cultured at stocking biomass more than 6.8 ton.ha ${ }^{-1}$. 


\section{Conclusions}

The result of this experiment indicated that $M$. lyrata grow very well in the intertidal areas in north coast of Vietnam during winter at water temperature of 23.59 $\pm 2.40^{\circ} \mathrm{C}$. The stocking biomass had strong effect on growth performance and survival of clam. For the stocking seed at shell length of $1.7 \mathrm{~cm}$, among 4 different stocking biomass $0.34,0.68,1.36$, and 2,04 kg. $\mathrm{m}^{-2}$, the higher biomass, the lower growth performance as well as the lower survival, which eventually resulted in reduction in the net profit even the final biomass were increasing. For the small seed at shell length of $1.0 \mathrm{~cm}$, among stocking biomass of $0.05,0.1,0.2$, and $0.3 \mathrm{~kg} \cdot \mathrm{m}^{-2}$, the lower stocking biomass resulted in better growth performance. The survival rate of the stocking biomass of $0.3 \mathrm{~kg} \cdot \mathrm{m}^{-2}$, however, was significantly lower than the others, and therefore, the highest net profit as well as investment return was obtained at the stocking biomass of $0.2 \mathrm{~kg} . \mathrm{m}^{-2}$. We recommend using this stocking biomass to maximize the profit of the cultivation.

Quality of the clam expressed as the meat ratio of clam was similar regardless of different stocking size or stocking biomass. In addition, the fatty acids of clam were rich in HUFAs especially DHA and EPA but also were showed differences between the treatments. This might be related to the natural feed availability or the different development stages of maturation; further research on this issue need to be addressed.

\section{Acknowledgments}

This research is a part of the collaboration project VIE 027/05 "Development of clam culture for improvement and diversification of livelihoods of the poor coastal communities in Central Vietnam" between the Aquaculture Research Sub-Institute for North Central (ARSINC-RIA1), Vietnam and the South Australian Research and Development Institute (SARDI), Australia. The project was funded by the AusAIDs through the Collaboration of Agriculture and Rural Development (CARD) program.

\section{References}

Cigarrýa, J., Fernandez, J.M. 2000. Management of Manila clam beds I. Influence of seed size, type of substratum and protection on initial mortality. Aquaculture 182:173-182.

Gibbs, M.T. 2004. Interactions between bivalve shellfish farms and fishery resources. Aquaculture 240:267-296.

Jara-Jara, R., A.J. Pazos, M. Abad, L.O. Garcia-Martin and J.L. Sanchez. 1997. Growth of clam seed (Ruditapes decussatus) reared in the wastewater effluent from a fish farm in Galicia (N. W. Spain). Aquaculture $158: 247-262$.

Mazzola, A., G. Sara. 2001. The effect of fish farming organic waste on food availability for bivalve molluscs (Gaeta Gulf, Central Tyrrhenian, MED): stable carbon isotopic analysis. Aquaculture 192:361-379.

Shpigel, M., and R. Fridman. 1990. Propagation of the Manila clam (Tapes semidecussatus) in the effluent of fish aquaculture ponds in Eilat, Israel. Aquaculture 90:113-122.

Shpigel, M. and R.A. Blaylock. 1991. The Pacific oyster Crassostrea gigas as a biological filter for a marine fish aquaculture pond. Aquaculture 92:187-197. 
Shpigel, M. and B. Spencer. 1996. Performance of diploid and triploid Manila clams (Tapes philippinarum, Adams and Reeve) at various levels of tidal exposure in the UK and in water from fish ponds at Eilat, Israel. Aquaculture 141:159-171.

Shpigel, M., A. Gasith and E. Kimmel. 1997. A biomechanical filter for treating fish-pond effluents. Aquaculture 152:103-117.

Shpigel, M., A. Neori, D.M. Popper and H. Gordin. 1993. A proposed model for "environmentally clean" land-based culture of fish, bivalves and seaweeds. Aquaculture 17:115-128.

Soudanta, P., C. Paillarda, G. Choqueta, C. Lamberta, H.I. Reidb, A. Marhica, L. Donaghya and T.H. Birkbeck. 2004. Impact of season and rearing site on the physiological and immunological parameters of the Manila clam Venerupis (=Tapes, =Ruditapes) philippinarum. Aquaculture 229:401-418.

Tacon, A.G.J. and M. Halwart. 2006. Cage culture: a global overview, Second International Symposium on Cage Aquaculture in Asia, Hangzhau, P. R. China.

Wang, N., R.S. Hayward and D.B. Noltie. 1998. Effect of feeding frequency on food consumption, growth, size variation, and feeding pattern of age-0 hybrid sunfish. Aquaculture 165:261-267.

Yan, X., G. Zhang and F. Yang. 2006. Effects of diet, stocking density, and environmental factors on growth, survival, and metamorphosis of Manila clam Ruditapes philippinarum larvae. Aquaculture 253:350-358.

Zhang, G. and X. Yan. 2006. A new three-phase culture method for Manila clam, Ruditapes philippinarum, farming in northern China. Aquaculture 258:452-461.

Zhuang, S. 2006. The influence of salinity, diurnal rhythm and daylength on feeding behavior in Meretrix meretrix Linnaeus. Aquaculture 252:584-590.

Zhuang, S.H. and Z.Q. Wang. 2004. Influence of size, habitat and food concentration on the feeding ecology of the bivalve, Meretrix meretrix Linnaeus. Aquaculture 241:689-699. 